\title{
Automobile Accessibility and the Allocation of Time - 1990-2010
}

\author{
Martin Brosnan and David M. Levinson
}

\author{
Martin Brosnan \\ CDM-Smith, \\ Department of Civil Engineering \\ University of Minnesota \\ 500 Pillsbury Dr SE \\ Minneapolis, MN 55455 \\ E-Mail: brosn024@umn.edu \\ David M. Levinson \\ RP Braun-CTS Chair of Transportation Engineering \\ Director of Network, Economics, and Urban Systems Research Group \\ University of Minnesota, Department of Civil, Environmental, and Geo- Engineering \\ 500 Pillsbury Drive SE \\ Minneapolis, MN 55455 USA \\ E-Mail: dlevinson@umn.edu \\ http://davidlevinson.org
}

\begin{abstract}
Using detailed travel surveys conducted by the Metropolitan Council of the Minneapolis/Saint Paul region for 1990, 2000-2001, and 2010-2011, this study analyzes journey-to-work times, activity allocation, and accessibility for automobile commuters. The analysis shows declines in the time people spent outside of their homes and in travel. Although distances per trip are increasing for workers, they are declining for non-workers. The number of trips is declining, resulting in less distance traveled and less time allocated to travel. This study finds accessibility to be a significant factor in commute durations. Accessibility and commute duration have large affects on the amount of time spent at work. We posit this is due to increased home-work blending.
\end{abstract}

JEL-Codes: J01, J22

Keywords: Travel duration, activity allocation, accessibility 


\section{Introduction}

Accessibility measures the potential for interactions (Cao et al. 2010, Geurs and Van Wee 2004, Grengs 2015, Hansen 1959, Haugen 2011, Tschopp et al. 2005, VanWee and Geurs 2011, Yang and Ferreira 2005). It is a function of both mobility (speed and directness of the network) and density of destinations. Simply put it is the number of destinations that can be reached in a given time. This study examines how accessibility affects time spent traveling to, and at, work for automobile commuters by examining three travel surveys conducted in different years in the Minneapolis - St. Paul (Twin Cities), Minnesota (USA) region.

While the Cleveland Regional Area Traffic Study in 1927 was the first such metropolitan survey sponsored by the US federal government, the lack of comprehensive survey methods and standards at that time precluded the systematic collection of information such as travel time, origin and destination, and traffic counts. The first US travel surveys appeared in urban areas after the Federal-Aid Highway Act of 1944 permitted the spending of federal funds on urban highways (Weiner 2012). A new home-interview origin-destination survey method was developed in which households were asked about the number of trips, purpose, mode choice, origin and destination of the trips conducted on a daily basis. In 1944, the US Bureau of Public Roads printed the Manual of Procedures for Home Interview Traffic Studies (United States Department of Commerce 1944). Highway engineers and urban planners made use of the new data collected after 1944 Highway Act extended federally sponsored planning to travel surveys as well as traffic counts, highway capacity studies, pavement condition studies and costbenefit analysis. As computer technologies have evolved from mainframe punched cards to reel tapes to minicomputers to personal computers, historic travel survey data are not always readily accessible. Moreover, because of the long timespan between surveys (sometimes 20 years), much institutional memory, the computer files, and even documentation are lost between surveys. While the methods for conducting such surveys have evolved over the past half-century (from in-person home interviews to computer administered telephone interviews (CATI)), and new methods like GPS devices are being tested, the basic data coming out of these surveys remains largely unchanged.

This project illustrates the utility of preserving and archiving travel surveys, as done in the Metropolitan Travel Survey Archive (http://surveyarchive.org). Travel surveys are useful instruments that provide valuable insight into the travel behavior characteristics of people at a city, county, state, or other geographical scales. Historical surveys help researchers to observe a temporal shift in travel preferences which may play an important role in making appropriate transportation related policies and producing better forecasts. With improved statistical techniques, a survey dataset may provide insight into the social behavior of the community. Use of data from the present and the past makes it possible to validate and calibrate new transportation planning models. 
Previous research using travel surveys has found that in US average commute trip durations have remained relatively stable over time, despite the changing urban landscape (Gordon et al. 1991, Levinson 1998, Levinson and Kumar 1994b, 1995, 1997). People travel increasingly on faster suburban roads rather than slower urban roads, and their destinations are becoming more decentralized. Decentralization and spread of both households and work locations increases distances. The extent to which this results in shorter commutes durations is disputed Cervero and Wu (1998) (and likely depends on context and existing congestion levels). A comprehensive literature review finds that household structure, demographics, destination activity, and the characteristics of the region traveled in found that all have measurable effects on travel time budgets (Mokhtarian and Chen 2004).

Using detailed travel surveys conducted by the Metropolitan Council of the Minneapolis/Saint Paul Region in Minnesota for 1990, 2000-2001, and 2010-2011, this paper analyzes journeyto-work times, activity allocation and accessibility. Given the data are collected every 10 years, we can observe changes in the travel behavior in the region, as well as any changes in the relationships important to the transportation network. This paper focuses on the behavior of auto commuters, for which there is a much larger sample size (and much larger mode share) in the Twin Cities region.

Subsequent sections in turn formulate the theory and hypotheses, describe the data, present the methodology, conduct a descriptive analysis, and then conduct a statistical modeling analysis of the data to test the hypotheses of the paper. The paper concludes with some implications for planning and research.

\section{Theory and hypotheses}

This study extends previous research by examining factors that affect travel and activity time use. E.g. Levinson (1998) used a gravity based accessibility model for the Washington, DC metropolitan area and applied it to data from a 1988 household survey to test several hypotheses that analyze the relationship between accessibility and the commuting times of various individuals.

The mechanisms by which travelers reach jobs through accessibility are a function of opportunities and competition. The more jobs available, the more likely a job will be accepted by a worker. Thus a higher accessibility to a desired trip end like jobs reduces time required to reach that trip end. However the more competitors who seek that same job, the less likely the job will actually be available (Shen 1998). Thus increased job accessibility in housing rich areas, and labor accessibility in employment rich areas are expected to decrease commute time. In brief the core hypotheses are formally defined below (extending and testing (Levinson 1998, Levinson and Kumar 1994b)):

- H1: Individuals living in areas that have high housing accessibility will have longer commutes due to competition for jobs. 
- H2: Individuals living in areas with high job accessibility will have shorter commutes because one of those jobs may be theirs.

- H3: Individuals working in areas that have high housing accessibility will have shorter commutes because they are more likely to live in said housing.

- H4: Individuals working in areas with many competing jobs will have longer commutes because they will have to search for housing further from their work due to competition in the housing market.

We would anticipate the same relationships for transit commuters were transit service as uniform as road networks. But the relationship is confounded by significant positive feedback between transit service and demand, as observed by the Mohring Effect (Mohring 1972). Increasing transit service reduces headways, which makes transit more attractive, which increases ridership, which may, in a virtuous circle, further reduce headways. This tends to occur in thick transit markets, which will occur where either job accessibility is high (i.e. high density job centers) or housing accessibility is high. Levinson (1998) found that transit commute durations drop when employment is higher near either the origin (home) or destination (work) end for trips.

Extending the analysis from travel duration to activity duration, we expect a relationship between accessibility and time spent at work. Two new hypotheses are tested relating accessibility and time spent at work:

- H5: Individuals with longer work journey times will spend more time at work.

- H6: Individuals with more daily work trips will spend less time spent at work.

While there is a finite amount of time and thus a budget (Levinson and Kanchi 2002), so more time at one activity must reduce time available for other activities, there are also complementarities between travel activities and out-of-home activities (travel and out-of-home activities are complements). The more out-of-home activities that are engaged in, the more travel that is employed to engage in them. The travel time ratio for work trips (work travel time / time spent at work) varies with socio-economic factors, but less with urban form (Schwanen and Dijst 2002). There could be several reasons for this.

Areas of high employment accessibility are associated with higher salaries (Melo et al. 2013). More productive employees (justifying the salary) work longer hours. The travel survey reports only household income, and it is impossible to identify from this data whether more hours cause higher annual salaries or higher wages per hour attract more hours of work, supporting $\mathrm{H} 5$.

Higher salary workers historically have been found to have longer commutes in the US. Higher salary workers have a greater choice in housing (they can afford both lower and higher cost houses, while lower income workers can only afford lower cost housing), which should give them a choice of closer housing. Higher income workers also by definition have a higher value of time, which also should push toward shorter commutes. However they may (or one 
might say, must) have a higher value of amenities (land, lakefront property, etc.) which can only be obtained farther from the workplace. This process is further complicated by twoincome households, which cannot necessarily jointly choose housing that is close to both workplaces.

Individuals with long commutes may work fewer days per week, but more hours per day, to compensate for the additional travel time. Unfortunately, a one-day travel diary cannot give us direct information about this. Studies of telecommuters using the same data find that telecommuting has no significant affect on the commute distance for single-worker households, and is negative for multi-worker households (Cao 2015), similarly supporting H5.

Individuals who work near their place of employment are able to travel back and forth between home and work readily, and may more easily blend the two. A person who lives near their job will, due to the easier commute, have more exibility in their hours (if the employer allows it), popping into the office as needed rather than needing to camp at their workplace in case something comes up. They may also be more likely to return home for lunch. We call this the Work-Home Blending explanation, and while it cannot be fully tested with the available data, would be supported by (H6). H6 could also be explained by more part-time jobs, or simply eating out (though not at home).

Finally, since we have multiple years, we can test whether the results are robust over time. We do this by examining significance and sign of the coefficients for H1-H6 for all three time periods.

- H7: The results are robust over time.

\section{Data}

The primary data for this study were collected by the Metropolitan Council for the Travel Behavior Inventories (TBI) conducted in 1990, 2000, and 2010. The TBI collects data on a variety of factors; from information about household size and makeup, employment information, and specific information about trips. A travel diary is included, which has selfreported travel times.

Due to the changing nature of the surveys in each decade, the data needed to be harmonized in order to be compared on a decade-to-decade basis. Also, much of the data is self-reported by the individuals who participated, and therefore there are errors in the reporting.

Certain censoring thresholds were used to address this issue. Trips were excluded if:

- The calculated distance traveled was greater than $200 \mathrm{~km}$ (though not technically impossible, any trip greater than this seemed unlikely and out of the realm of the analysis).

- The calculated average speed was greater than $150 \mathrm{~km}^{*} \mathrm{H}^{-1}$ (again, not technically an impossibility, however an average speed that fast would be highly unlikely, and some calculated speeds were impossibly high). 
- Trip durations exceeded than 120 minutes. While durations greater than that may or may not be errors, it was determined that they fell beyond a reasonable application of this study. Or,

- Any of the fields were missing or unreported.

When a trip was omitted, so were all of the other trips made by that respondent, so as not to artificially affect the time allocations.

Table 1 shows the filtering parameters and the remaining sample size for each year after the filters. Most of the filtering and analysis of the data in this study are the same as Levinson and $\mathrm{Wu}$ (2005), which analyzed TBI data from 1990 and 2000, however with a few definitional changes in order to directly compare 2000 with 2010. Only adult respondents of working age were used (between 18 and 65), as well as only respondents who had begun and ended the travel day at home. The latter parameter is needed to calculate the time spent at home. In Levinson and $\mathrm{Wu}(2005)$ the respondents were separated by gender and employment status, however telecommuting was not taken into account. Additionally, anyone who made a trip reported to be greater than 120 minutes was excluded. This is due to the assumption that they are making "unusual" trips, rather than a daily routine trip. There is no guarantee that the remaining records represent usual or typical behavior for any particular individual. Telecommuting is becoming a significant means of employment, which may have deep impacts on the transportation network, however for the purposes of comparison to Levinson and $\mathrm{Wu}$ (2005), it was decided to omit the work-at-home category for this study as well.

The trip purposes for each separate TBI were harmonized, as defined in Owen et al. (2015). A worker is defined as someone who made a work-trip on the travel day. A work-at-home respondent is defined as someone who did not have a work outside of home trip on the travel day but did have work-at-home listed as an activity.

One significant difference between this study and Levinson and $\mathrm{Wu}$ (2005) is the inclusion of "work-related" trips as work trips, and the inclusion of formerly "non-workers" who made work related trips into the worker category. This change was made due to the 2010 TBI lacking a "work-related trip" purpose. In the 2010 survey, a work trip included any trip made for work outside of the home, regardless of whether that trip was to the primary place of employment or not. This change affected the 1990 and 2000 results, and as such they were recalculated, as discussed later in this report. The sample size of each category can be seen in Figure 1. Filtering may introduce bias compared to the original sample, though the original sample is, despite efforts, not unbiased either compared to the population. Weights are not used in the statistical analysis below. 
Table 1

Filtering

\begin{tabular}{lrrr}
\hline Description of Constraints & $\mathbf{1 9 9 0}$ & $\mathbf{2 0 0 0}$ & $\mathbf{2 0 1 0}$ \\
\hline Subtotal & 24509 & 14671 & 30286 \\
Reason for dropping records & & & \\
Gender not recorded & 0 & 0 & 45 \\
Age [18,65] & 7513 & 6279 & 11992 \\
Did not start travel day at home & 975 & 237 & 700 \\
Did not end travel day at home & 385 & 209 & 1820 \\
Trip Duration > 120 & 31 & 17 & 653 \\
Travel+activity duration > 1440 & 63 & 5 & 91 \\
Missing 1 or more trips & 60 & 266 & 535 \\
Work-at-home only & 20 & 70 & 698 \\
Total dropped & 9047 & 7083 & 16534 \\
Net total & 15462 & 7588 & 13572 \\
\hline
\end{tabular}

Source: Metropolitan Council for the Travel Behavior Inventories (TBI) 1990, 2000, and 2010, own calculations.

Figure 1 Sample Distribution

\section{Sample Size Distribuion (samole size in parenthesis)}

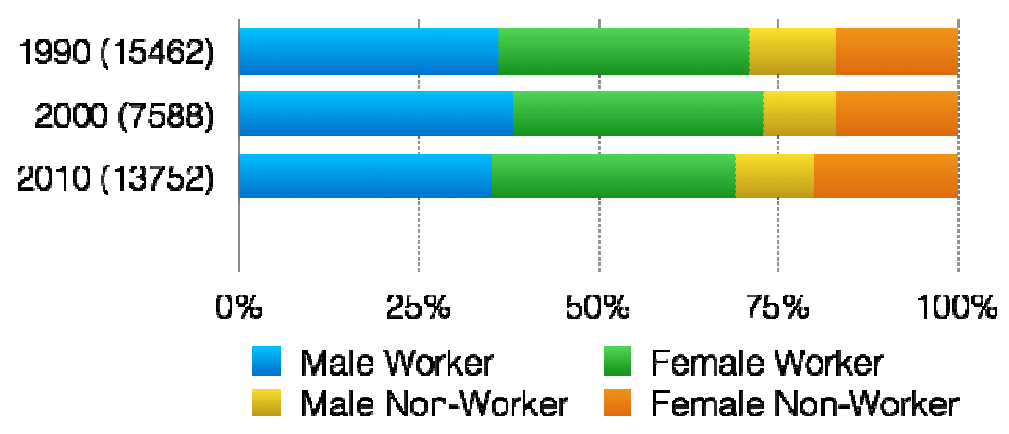

Source: Metropolitan Council for the Travel Behavior Inventories (TBI) 1990, 2000, and 2010, own illustrations.

The Metropolitan Council divided the 7-county region into 1201 Transportation Analysis Zones (TAZs) for the 2000 TBI Guidelines (n.d.). These TAZs allow for a higher resolution of data than just municipality level statistics, especially for the large cities of Minneapolis and Saint Paul. Different TAZ systems were in use for the different surveys. For this analysis the year $2000 \mathrm{TAZ}$ system is used to be consistent with the accessibility calculations that are used.

For all years, accessibilities were calculated based on a cumulative opportunities model, where the number of opportunities from a TAZ given a certain travel time threshold (in minutes) is calculated. Additional population and employment data were collected from the 
United States Census Bureau. Accessibility measures for 2010 were calculated by (Owen and Levinson 2012). The auto accessibilities for 1995 and 2000 were computed by (El-Geneidy and Levinson 2006).

\section{Methods}

The activity durations were calculated by linking the trips taken by each respondent and then subtracting the arrival time of the former trip from the departure time of the latter. The remaining time was calculated by adding the travel times for each trip to the calculated activity durations and subtracting the total from 1440 minutes. This time was cross-checked by subtracting the time of departure of the first trip from midnight and the last trips' arrival from midnight and adding the two. This remaining time was attributed to time at home due to the filter that all respondents began and ended their travel days at home. Figure 2 illustrates this calculation process on an idealized data set.

\section{Figure 2}

\section{Activity Duration Calculation}

\begin{tabular}{|c|c|c|c|c|c|c|c|}
\hline $\begin{array}{c}\text { Person } \\
\text { ID }\end{array}$ & Origin & Destination & $\begin{array}{c}\text { Trip } \\
\text { departure } \\
\text { time }\end{array}$ & $\begin{array}{c}\text { Trip } \\
\text { arrival } \\
\text { time }\end{array}$ & Travel time & $\begin{array}{c}\text { Activity } \\
\text { Duration } \\
\text { (min) }\end{array}$ & Total \\
\hline 1 & Home & Shop & $8: 30$ & 15 & 30 & 45 \\
\hline 1 & Shop & Work & $9: 15$ & 15 & 360 & 420 \\
\hline 1 & Work & Dining & $15: 30$ & $15: 30$ & 105 & 540 \\
\hline 1 & Dining & Shop & $17: 30-17: 40$ & 10 & 20 & 570 \\
\hline 1 & Shop & Home & $18: 00-18: 20$ & 10 & 850 & 1440 \\
\hline 2 & Home & Work & $8: 00-8: 20$ & 20 & & 360 \\
\hline
\end{tabular}

Source: Metropolitan Council for the Travel Behavior Inventories (TBI) 1990, 2000, and 2010, own illustrations.

Each activity's allocation of time was calculated by taking the mean of the activity durations for each gender/employment category, where the total sample size was the size of that category. This equates to the average time that each respondent spent on that activity, including those who did not partake in that activity on the travel day. Thus, each category represents a time budget that adds to a total of 1440 minutes. The results from 2000 were compared to 1990, while the results from 2010 were compared to both 1990 and 2000 using a t-test to determine if any changes were significant.

In order to analyze the effects of suburbanization in the region, the network distances to the central business district (CBD) were calculated. It is assumed that the density of development decreases, and the average velocities of vehicles increase as distance to the CBD increases. 
These factors are all intertwined with accessibility, but also looked at independently and in relation to accessibility. Due to the nature of the Minneapolis - Saint Paul region being the "Twin Cities" and essentially having two CBDs, the distances were calculated from both. All trips were then placed into categories based on their minimum distance to the CBDs (for example, if a trip origin was closer to Downtown Minneapolis than Downtown Saint Paul, its category was determined by its distance to Downtown Minneapolis.)

Accessibility is defined using a cumulative opportunities measure (Vickerman 1974, Wachs and Kumagai 1973). Here, the Cumulative Opportunity measure counts the number of jobs in a given travel time threshold. The cumulative opportunity measure for job accessibility is typically expressed as,

$$
\begin{aligned}
& A_{T, i}=\sum_{j} O_{j} f\left(C_{i j}\right) \\
& f\left(C_{i j}\right)=\left\{\begin{array}{cc}
1 & \text { ifC }_{\mathrm{ij}} \leq \mathrm{T} \\
0 & \text { ifCij }>T
\end{array}\right.
\end{aligned}
$$

Where:

$A_{T, i}-$ job accessibility of block i, within threshold T

$O_{j}$ - jobs in block $\mathrm{j}$,

$C_{i j}$ - shortest travel time between block i and block $\mathrm{j}$,

$T$ - the travel time threshold.

This measure of cumulative opportunity is calculated for each TAZ for multiple time thresholds. To avoid multi-collinearity, a composite weighted accessibility $\left(\mathrm{A}_{\mathrm{W}, \mathrm{i}}\right)$ at each TAZ was calculated by using the equation

$$
A_{W, i}=\sum_{j}\left(A_{T, i}-A_{T-Z, i}\right) e^{\theta x}
$$

Where:

$A_{T, i}=$ accessibility within $\mathrm{T}$ minute threshold (10, 20, 30, 40, 50, or 60 minutes).

$A_{T-Z, i}=$ accessibility within the previous minute threshold, where $\mathrm{Z}$ is the threshold size (10 minutes).

$\theta=$ travel time decay factor

The travel time decay factor $\theta$ has previously been estimated to be -0.08 using data from the Washington DC (DC) region (Levinson and Kumar 1994a). To ensure comparability between the Twin Cities and DC models, that value is retained in the results presented herein. If $\theta$ were zero, then people are indifferent to travel time. If $\theta$ is very negative, people are very sensitive to travel time, and value close destinations much more highly than far away destinations.

This weighted accessibility calculation combines the multiple cumulative opportunities accessibility measures (the exact number of opportunities available within a certain travel cost) into 
a gravity-like model of accessibility, and maintains comparability with Levinson (1998). In order to test the validity of this model (specifically the $\theta$ coefficient of -0.08 ) for the Twin Cities region, the regression analysis was tested using a variety of coefficients for 2010 . A large test of alternative model formulations can be found in Brosnan (2014).

An OLS regression was performed for auto users where the dependent variable was the commute duration. Using the same explanatory variables as previous studies allows for direct comparison to the DC results, with a few exceptions; the addition of workers aged $70+$ to the age 60 category, since there were none in the 2010 and 1990 samples, and very few in 2000, and the elimination of the female head of household variable, since the TBI survey did not record that and it would be difficult to determine from the questions asked to the same confidence as the DC study.

A second analysis was conducted with the dependent variable as the time allocated to work for auto commuters. For these regressions, the data was organized by worker (based on the previously stated criteria) and an additional explanatory variable of the number of work trips made that day was added. Income as an explanatory variable was initially found to be insignificant, but was removed from the regression due to the multitude of problems with the income records in the TBI; the income is recorded for the household, not at the person level, it is self reported, and more than half of the survey respondents declined to answer the question, which greatly reduced the sample size and accuracy of the regressions.

Regressions were conducted for work duration using only the accessibility variables (plus demographics), with commute duration substituting for accessibility, and with predicted commute duration from the best fit model as a substitute for accessibility. Results with predicted time are reported here. Additional results can be found in Brosnan (2014).

\section{$5 \quad$ Descriptive Analysis}

Table 2 shows the characteristics of trips taken in the region (speeds are in $\mathrm{km}^{*} \mathrm{H}^{-1}$ ). Trip durations for workers have risen for all activities from 2000 to 2010, but for non-workers it has gone down. This rise may be due to economic factors in that workers may have taken less desirable jobs based on distance from their homes, or caused people to move further from their workplace. In addition specialization may increase commute distances, particularly in two-worker households. The latter may have had an effect on non-work trips as well. Despite trip durations being higher, the daily time spent in travel for non-workers (and overall) is down (see Table 3). This observation matches other research that shows that less time is being spent traveling, as evidenced by a decrease in the total vehicle travel in the United States (Levinson and Krizek 2015, United States Department of Transportation, Federal Highway Administration 2013). Interestingly, the average trip duration for 2000 and 2010 did not change much (18 minutes for 2000 and 19 minutes for 2010), implying that the reductions are in the willingness to make a trip, but not based on the distance of said trip. 
Table 2

Average travel times (minutes) and travel distances $(\mathbf{k m})$ auto

\begin{tabular}{|c|c|c|c|c|c|c|c|c|c|c|}
\hline \multirow[b]{2}{*}{ Distination } & & \multirow[b]{2}{*}{ Year } & \multicolumn{4}{|c|}{ Worker } & \multicolumn{4}{|c|}{ Non-Worker } \\
\hline & & & Male & Std. Dev. & Female & Std. Dev. & Male & Std. Dev. & Female & Std. Dev. \\
\hline \multirow[t]{9}{*}{ Work } & Time & 1990 & 23.1 & 16.8 & 20.2 & 14.9 & & & & \\
\hline & Time & 2000 & 22.8 & $16.9 *$ & 19.8 & $15.3 *$ & & & & \\
\hline & Time & 2010 & 23.9 & $16.8 * * *$ & 21.6 & $15.3^{* * *}$ & & & & \\
\hline & Distance & 1990 & 11.0 & 15.2 & 8.4 & 12.1 & & & & \\
\hline & Distance & 2000 & 12.1 & $16.9 *$ & 9.8 & 13.7 & & & & \\
\hline & Distance & 2010 & 14.2 & $15.6 * * *$ & 12.3 & $13.2 * *$ & & & & \\
\hline & Speed & 1990 & 28.6 & & 25.0 & & & & & \\
\hline & Speed & 2000 & 31.8 & & 29.7 & & & & & \\
\hline & Speed & 2010 & 35.6 & & 34.2 & & & & & \\
\hline \multirow[t]{9}{*}{ Shop } & Time & 1990 & 12.9 & 11.5 & 12.4 & 12.0 & 13.8 & 12.3 & 12.4 & 12.5 \\
\hline & Time & 2000 & 13.2 & 11.7 & 13.0 & 11.7 & 14.2 & $13.1 *$ & 12.8 & $12.3^{*}$ \\
\hline & Time & 2010 & 15.4 & $13.7 * * *$ & 14.1 & $12.1 * * *$ & 13.6 & $12.7 *$ & 12.4 & $11.0 *$ \\
\hline & Distance & 1990 & 7.2 & 6.4 & 6.3 & 6.4 & 7.3 & 11.2 & 7.2 & 10.9 \\
\hline & Distance & 2000 & 7.6 & $12.1 *$ & 6.8 & $11.5^{*}$ & 7.4 & 12.3 & 7.3 & 12.6 \\
\hline & Distance & 2010 & 8.4 & $11.0 * * *$ & 7.1 & $9.6 * *$ & 7.0 & 10.8 & 6.5 & $9.5 * * *$ \\
\hline & Speed & 1990 & 33.5 & & 30.5 & & 31.7 & & 34.8 & \\
\hline & Speed & 2000 & 34.5 & & 31.4 & & 31.3 & & 34.2 & \\
\hline & Speed & 2010 & 32.7 & & 30.2 & & 30.9 & & 31.5 & \\
\hline \multirow[t]{9}{*}{ Other } & Time & 1990 & 16.4 & 14.2 & 13.4 & 12.9 & 18.4 & 16.4 & 15.6 & 15.2 \\
\hline & Time & 2000 & 16.6 & 15.5 & 14.6 & 13.3 & 18.2 & 16.8 & 15.3 & $14.6^{*}$ \\
\hline & Time & 2010 & 16.6 & 14.6 & 15.5 & $13.1 * * *$ & 17.8 & $15.7 * *$ & 15.8 & $13.6^{*}$ \\
\hline & Distance & 1990 & 7.8 & 12.9 & 7.8 & 12.2 & 10.2 & 13.4 & 8.0 & 10.9 \\
\hline & Distance & 2000 & 8.2 & 15.4 & 7.2 & 12.3 & 9.8 & 15.3 & 8.1 & 12.4 \\
\hline & Distance & 2010 & 8.9 & 7.6 & 8.1 & 10.3 & 9.2 & $13.1 * *$ & 7.9 & 9.5 \\
\hline & Speed & 1990 & 28.5 & & 34.9 & & 33.3 & & 30.8 & \\
\hline & Speed & 2000 & 29.6 & & 29.6 & & 32.3 & & 31.8 & \\
\hline & Speed & 2010 & 32.2 & & 31.4 & & 31.0 & & 30.0 & \\
\hline
\end{tabular}

This decline in the amount of time spent travelling has been a topic recently in the transportation field. The rate of change in total vehicle travel has been steadily decreasing, and the per capita total distance travelled has begun to decline. As technologies change, the attitude towards cars and car travel has also changed, with the car becoming a less desirable form of transportation to alternatives or simply not making a trip (Metz 2010). The term "Peak Travel" has been used to describe the idea that travel growth in the United States has ceased and 
may begin to decline (Millard-Ball and Schipper 2011). The results of this study indicate that, while per trip times remain largely steady, total travel is declining in the Twin Cities region.

Table 3 summarizes the allocation of time over these three surveys. The time spent working for both genders and both work from home and work outside of home have decreased by a large amount. This is in part due to the economic recession of 2008, which caused a rise in the number of part-time laborers (United States Census Bureau 2012). However there has also been a decade-long decline in labor force participation rates beginning prior to the 2008 recession (United States Department of Labor 2014).

Table 3

Activity durations auto (minutes)

\begin{tabular}{|c|c|c|c|c|c|c|c|c|c|}
\hline \multirow[b]{2}{*}{ Activity } & \multirow[b]{2}{*}{ Year } & \multicolumn{4}{|c|}{ Workers } & \multicolumn{4}{|c|}{ Non-Workers } \\
\hline & & Male & Std. Dev. & Female & Std. Dev. & Male & Std. Dev. & Female & Std. Dev. \\
\hline \multirow[t]{3}{*}{ Home } & 1990 & 777 & 286 & 816 & 302 & 1101 & 453 & 1172 & 482 \\
\hline & 2000 & 778 & 340 & 809 & 349 & 1082 & 482 & 1140 & 485 \\
\hline & 2010 & 787 & 340 & 825 & 351 & 1175 & 494 & 1175 & 486 \\
\hline \multirow[t]{3}{*}{ Work } & 1990 & 514 & 206 & 477 & 198 & & & & \\
\hline & 2000 & 502 & 237 & 471 & 205 & & & & \\
\hline & 2010 & 495 & 218 & 470 & 202 & & & & \\
\hline \multirow[t]{3}{*}{ Shop } & 1990 & 7 & 22 & 15 & 32 & 21 & 43 & 41 & 61 \\
\hline & 2000 & 8 & 38 & 14 & 31 & 21 & 43 & 41 & 61 \\
\hline & 2010 & 5 & 64 & 9 & 44 & 32 & 74 & 41 & 53 \\
\hline \multirow[t]{3}{*}{ Other } & 1990 & 52 & 85 & 55 & 79 & 143 & 167 & 132 & 144 \\
\hline & 2000 & 59 & 78 & 62 & 67 & 243 & 192 & 177 & 128 \\
\hline & 2010 & 65 & 72 & 55 & 64 & 171 & 134 & 161 & 115 \\
\hline \multirow[t]{3}{*}{ Travel } & 1990 & 88 & 22 & 77 & 20 & 79 & 21 & 80 & 20 \\
\hline & 2000 & 93 & 17 & 84 & 15 & 82 & 16 & 81 & 14 \\
\hline & 2010 & 87 & 17 & 81 & 15 & 73 & 15 & 74 & 14 \\
\hline
\end{tabular}

Source: Metropolitan Council for the Travel Behavior Inventories (TBI) 1990, 2000, and 2010, own calculations.

Total time spent shopping decreased for everyone except for non-working females, likely caused in part by an increase in online shopping, as well as economic factors. According to the United States Census Bureau, the percentage of households in the United States that had access to the Internet increased from $41.5 \%$ in 2000 to $71.7 \%$ in 2011 (United States Census Bureau 2013). The Internet has provided electronic accessibility, much as the transportation network has in the material world. It helps to facilitate commerce, communication, education, and leisure. This may lead to a decreased need for people to travel, and account for more time spent at home. The recession of 2008 may have had an impact on shopping traveling habits as a reduction in the household budgets for luxuries such as eating out, shopping for unemployed persons, but also those nervous about the potential of unemployment. Further, time spent in all other activities also declined from 2000 to 2010. These decreases require a concomitant increase in the amount of time spent at home. 


\section{Results}

Tables 4 tests and largely corroborates H1-H4: 11 of 12 results (4 models for 3 time periods) were significant and had the expected sign, with the exception of resident accessibility in 2010 auto users, which was not-significant. These models used the same variables as the DC study (with a few modifications, see Section 4). This allows for a comparison between the different regions. In these 11 cases, the relationships of the accessibility variables retain the same signs as the DC study.

Table 4

Models of commuting duration by auto

\begin{tabular}{|c|c|c|c|c|}
\hline & DC & 2010 MSP & 2000 MSP & 1990 MSP \\
\hline Age 10-19 & $\begin{array}{l}-5.85 * * * \\
(-2.75)\end{array}$ & $\begin{array}{l}-5.76 * * * \\
(-2.98)\end{array}$ & $\begin{array}{l}-6.92 * * * \\
(-3.26)\end{array}$ & $\begin{array}{l}-5.87 * * * \\
(-4.12)\end{array}$ \\
\hline Age 20-29 & $\begin{array}{l}1.90 * * \\
(1.96)\end{array}$ & $\begin{array}{l}-1.38^{* *} \\
(-1.75)\end{array}$ & $\begin{array}{l}-1.216^{*} \\
(-1.42)\end{array}$ & $\begin{array}{l}-0.28 * * * \\
(-0.26)\end{array}$ \\
\hline Age 40-49 & $\begin{array}{l}0.434 \\
(0.50)\end{array}$ & $\begin{array}{r}0.65 \\
(1.12)\end{array}$ & $\begin{array}{l}0.643 \\
(2.31)\end{array}$ & $\begin{array}{l}0.697 \\
(1.25)\end{array}$ \\
\hline Age 50-59 & $\begin{array}{r}-0.62 \\
(-0.62)\end{array}$ & $\begin{array}{l}-1.04 * * \\
(-1.85)\end{array}$ & $\begin{array}{r}-0.44 \\
(-0.61)\end{array}$ & $\begin{array}{r}-0.35 \\
(-0.76)\end{array}$ \\
\hline Age $60+$ & $\begin{array}{r}-0.77 \\
(-0.56)\end{array}$ & $\begin{array}{r}-0.83 \\
(-1.19)\end{array}$ & $\begin{array}{r}-0.52 \\
(-0.35)\end{array}$ & $\begin{array}{r}-0.62 \\
(-0.42)\end{array}$ \\
\hline Male & $\begin{array}{l}1.82 * * \\
(2.52)\end{array}$ & $\begin{array}{l}1.53 * * * \\
(4.26)\end{array}$ & $\begin{array}{l}1.79 \text { *** } \\
(5.12)\end{array}$ & $\begin{array}{l}1.42 * * \\
(4.32)\end{array}$ \\
\hline SF home & $\begin{array}{r}0.16 \\
(0.18)\end{array}$ & $\begin{array}{r}-0.155 \\
(-0.275)\end{array}$ & $\begin{array}{r}-0.78 \\
(-0.41)\end{array}$ & $\begin{array}{r}-1.23 \\
(-0.31)\end{array}$ \\
\hline Vehicles per driver & $\begin{array}{r}1.03 \\
(1.07)\end{array}$ & $\begin{array}{l}0.179 * * \\
(0.44)\end{array}$ & $\begin{array}{c}1.24 * \\
(0.98)\end{array}$ & $\begin{array}{l}1.09 * * \\
(1.27)\end{array}$ \\
\hline Children & $\begin{array}{l}0.936^{*} \\
(1.72)\end{array}$ & $\begin{array}{r}-0.341 \\
(-0.948)\end{array}$ & $\begin{array}{r}0.32 \\
(1.02)\end{array}$ & $\begin{array}{r}0.12 \\
(0.15)\end{array}$ \\
\hline HH size & $\begin{array}{r}0.0857 \\
(0.24)\end{array}$ & $\begin{array}{r}0.196 \\
(0.909)\end{array}$ & $\begin{array}{r}0.22 \\
(1.05)\end{array}$ & $\begin{array}{r}0.19 \\
(1.03)\end{array}$ \\
\hline $\mathrm{A}_{\mathrm{iEa}}$ & $\begin{array}{c}-8.68 \mathrm{E}-05^{* * *} \\
(-4.86)\end{array}$ & $\begin{array}{c}-1.60 \mathrm{E}-05^{* *} \\
(-1.97)\end{array}$ & $\begin{array}{c}-7.231 \mathrm{E}-06^{* * * *} \\
(-3.214)\end{array}$ & $\begin{array}{c}-7.892 \mathrm{E}-06 * * * \\
(-2.923)\end{array}$ \\
\hline $\mathrm{A}_{\mathrm{iRa}}$ & $\begin{array}{l}1.18 \mathrm{E}-04 * * * \\
(2.75)\end{array}$ & $\begin{array}{r}-1.14 \mathrm{E}-05 \\
(-0.869)\end{array}$ & $\begin{array}{c}1.989 \mathrm{E}-05 * * * \\
(2.43)\end{array}$ & $\begin{array}{c}2.003 \mathrm{E}-05^{* *} \\
(2.63)\end{array}$ \\
\hline $\mathrm{A}_{\mathrm{jEa}}$ & $\begin{array}{c}\text { 7.13E-05*** } \\
(4.21)\end{array}$ & $\begin{array}{c}3.73 \mathrm{E}-05 * * * \\
(5.04)\end{array}$ & $\begin{array}{c}3.68 \mathrm{E}-05 * * * \\
(4.29)\end{array}$ & $\begin{array}{c}3.02 \mathrm{E}-05^{* * * *} \\
(5.02)\end{array}$ \\
\hline $\mathrm{A}_{\mathrm{jRa}}$ & $\begin{array}{c}-1.47 \mathrm{E}-04 * * * \\
(-3.26)\end{array}$ & $\begin{array}{c}-4.03 \mathrm{E}-05^{* * * *} \\
(-3.17)\end{array}$ & $\begin{array}{c}-2.72 \mathrm{E}-05^{* * * *} \\
(2.46)\end{array}$ & $\begin{array}{c}-3.09 \mathrm{E}-05^{* * * *} \\
(-3.02)\end{array}$ \\
\hline$D_{\text {io }}$ & $\begin{array}{l}0.63 * * * \\
(5.82)\end{array}$ & $\begin{array}{c}2.75 \mathrm{E}-02 * * \\
(2.71)\end{array}$ & $\begin{array}{c}0.43^{* *} \\
(4.036)\end{array}$ & $\begin{array}{l}0.53 * * * \\
(5.23)\end{array}$ \\
\hline $\mathrm{D}_{\mathrm{jo}}$ & $\begin{array}{l}-0.55 * * * \\
(-3.77)\end{array}$ & $\begin{array}{c}-5.21 \mathrm{E}-02 * * * \\
(-4.31)\end{array}$ & $\begin{array}{l}-0.32 * * \\
(-2.29)\end{array}$ & $\begin{array}{l}-0.30 * * \\
(-3.02)\end{array}$ \\
\hline
\end{tabular}


Table 4 (Cont.)

\begin{tabular}{lcccc}
\hline & DC & 2010 MSP & 2000 MSP & 1990 MSP \\
\hline Constant & $23.29 * * *$ & $28.26 * * *$ & $25.42 * * *$ & $24.32 * * *$ \\
& $(4.61)$ & $(11.30)$ & $(9.85)$ & $(11.26)$ \\
Sample Size & 1950 & 5228 & 2978 & 6574 \\
Adj. $\mathrm{R}^{2}$ & 0.17 & 0.1398 & 0.14 & 0.142 \\
$\mathrm{~F}$ & $22.79 * * *$ & $52.94 * * *$ & $42.21 * * *$ & 44.26 \\
\hline
\end{tabular}

* indicates $\mathrm{P}<0.10, * *$ indicates $\mathrm{P}<0.05$, *** indicates $\mathrm{P}<0.01$, Source: Metropolitan Council for the Travel Behavior Inventories (TBI) 1990, 2000 , and 2010, own calculations.

Some of the other significant demographic variables differ in their signs. These differences may be related to different external factors that govern behavior for the different regions. Similarly, the magnitudes of the coeffcients of the models differ likely due to both the different accessibility and other definitions, as well as the different urban structure between the two cities (amongst other factors such as culture and changing dynamics over time).

Figure 3

\section{Employment Accessibility by Auto}

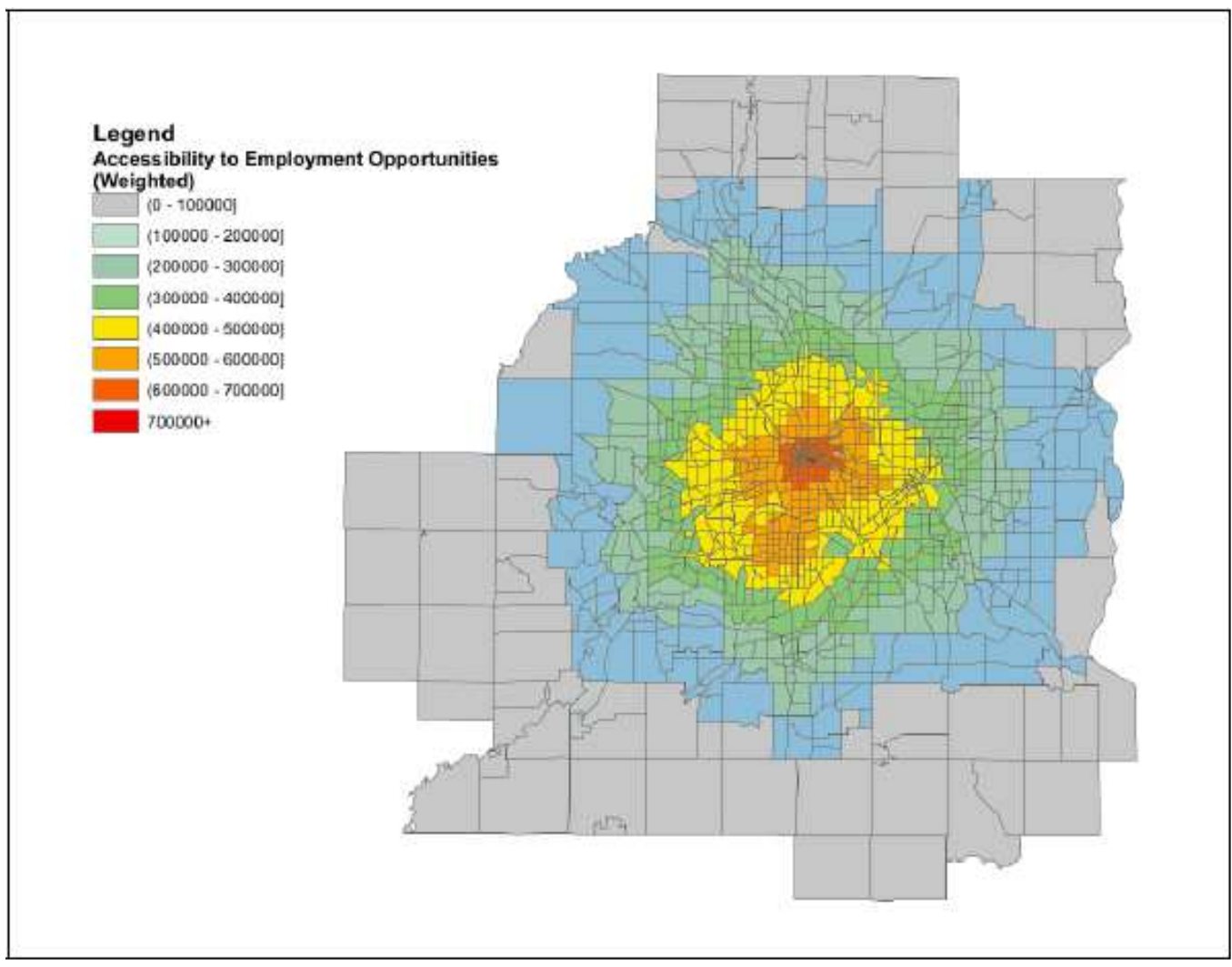

Source: Metropolitan Council for the Travel Behavior Inventories (TBI) 1990, 2000, and 2010, own illustrations.

Table 5 shows the results of the regressions to predict the time spent at work. Commute duration is positively associated with time at work, corroborating H5, and supportive of the home- 
work blending hypothesis. Similarly the number of work trips per day is negatively associated with time at work, corroborating H6. The relationships appear to be relatively stable over time, supporting $\mathrm{H} 7$.

Table 5

Regressions to predict time at work for auto users using predicted travel times

\begin{tabular}{|c|c|c|c|}
\hline & 2010 & 2000 & 1990 \\
\hline Age 10-19 & $\begin{array}{l}-64.8 * * \\
(-2.14)\end{array}$ & $\begin{array}{l}-57.77 * * \\
(-1.90)\end{array}$ & $\begin{array}{l}-48.32 * * \\
(-1.59)\end{array}$ \\
\hline Age $20-29$ & $\begin{array}{r}-10.7 \\
(-0.982)\end{array}$ & $\begin{array}{r}-12.278 \\
(-1.12)\end{array}$ & $\begin{array}{r}-13.066 \\
(-1.19)\end{array}$ \\
\hline Age $40-49$ & $\begin{array}{r}1.74 \\
(0.252)\end{array}$ & $\begin{array}{r}1.818 \\
(0.26)\end{array}$ & $\begin{array}{r}2.077 \\
(0.3)\end{array}$ \\
\hline Age 50-59 & $\begin{array}{l}14.8^{* *} \\
(1.975)\end{array}$ & $\begin{array}{l}13.745^{* *} \\
(1.83)\end{array}$ & $\begin{array}{l}13.523^{* *} \\
(1.8)\end{array}$ \\
\hline Age $60+$ & $\begin{array}{r}-8.74 \\
(-1.053)\end{array}$ & $\begin{array}{r}-10.191 \\
(-1.22)\end{array}$ & $\begin{array}{l}-9.351 \\
(-1.12)\end{array}$ \\
\hline Male & $\begin{array}{l}25^{* * *} \\
(4.78)\end{array}$ & $\begin{array}{l}4.184 \\
(0.63)\end{array}$ & $\begin{array}{l}4.284 \\
(0.64)\end{array}$ \\
\hline SF home & $\begin{array}{r}-3.94 \\
(-0.587)\end{array}$ & $\begin{array}{l}-3.959 \\
(-0.58)\end{array}$ & $\begin{array}{l}-3.487 \\
(-0.51)\end{array}$ \\
\hline Vehicles per driver & $\begin{array}{l}11.3 * * \\
(2.367)\end{array}$ & $\begin{array}{l}12.377 * * \\
(2.59)\end{array}$ & $\begin{array}{l}10.185^{* *} \\
(2.13)\end{array}$ \\
\hline Children & $\begin{array}{l}-10.4^{* *} \\
(-2.432)\end{array}$ & $\begin{array}{l}-12.197 * * \\
(-2.85)\end{array}$ & $\begin{array}{l}-13.067 * * \\
(-3.05)\end{array}$ \\
\hline HH size & $\begin{array}{r}-0.455 \\
(-0.178)\end{array}$ & $\begin{array}{r}-0.38 \\
(-0.14)\end{array}$ & $\begin{array}{r}-0.41 \\
(-0.16)\end{array}$ \\
\hline Number of work trips & $\begin{array}{l}-150 * * * \\
(-43.759)\end{array}$ & $\begin{array}{l}-146.634 * * * \\
(-42.77)\end{array}$ & $\begin{array}{l}-123.232 * * * \\
(-35.9)\end{array}$ \\
\hline $\begin{array}{l}\text { Predicted Commute Dura- } \\
\text { tion }\end{array}$ & $\begin{array}{l}10.5^{* * * *} \\
(3.001)^{-1}\end{array}$ & $\begin{array}{l}9.15^{* * * *} \\
(2.61)\end{array}$ & $\begin{array}{l}8.55^{* * * *} \\
(2.44)\end{array}$ \\
\hline Constant & $\begin{array}{l}772 * * * \\
(21.43)\end{array}$ & $\begin{array}{c}266.388 * \\
(2.13)\end{array}$ & $\begin{array}{c}251.157^{*} \\
(2.01)\end{array}$ \\
\hline Sample Size & 5228 & 2978 & 6574 \\
\hline Adj. $\mathrm{R}^{2}$ & 0.274 & 0.2987 & 0.2964 \\
\hline $\mathrm{F}$ & $165.4 * * *$ & $162.1 * * *$ & $164.5 * * *$ \\
\hline
\end{tabular}

The main factors that affect time spent at work are age, the number of work (destination) trips and commute duration. Age plays a large role, especially at the younger brackets due to younger workers being more likely to work part-time shifts, with people in their 20 s to 40 s spending the most time at work. The effect of the number of work trips was at least in part because of the way the data were recorded, if a person left for a lunch break or on an errand during the work day on personal business, that would likely show up as multiple work trips, whereas someone who ate their lunch at their workplace would have that lunch time included 
in their time at work. Interestingly, the number of children one has, while a significant factor statistically, did not decrease the time spent at work by a large amount.

\section{Conclusion}

The results of this analysis show a measurable decline in the time people spend outside of their homes as well as the amount of time people spend in travel over the past decade. The rise of the Internet and mobile telecommunications and changes in the economy between 2000 and 2010, along with changing demographics and new modes of work may be among the factors causing people to reconsider the necessity of travel. Although trip distances per trip are getting longer the willingness to make those trips is declining, and as a result fewer kilometers are being traveled and less time on average is being allocated to travel per capita.

This study corroborates, updates, and extends previous studies showing that accessibility is a significant factor in commute durations. Though commutes do not make the majority of trips in the US, even during the peak (Pisarski 1987, 1996, 2006), they are the most important and regular trips made by workers (about half the population), and do constitute a majority of travel distance in peak hours. This study shows that the accessibility pattern within a city affects average commute durations and time spent at work.

In addition, this study shows a correlation between commute duration and the amount of time spent at work. Further analysis into the cause of this should try to directly test the extent to which this is due to a blending of the work and home environments when workers live near their jobs. Further research should also investigate these behaviors for other modes in more depth (transit is examined in Brosnan 2014).

Finally, the results are robust, even as travel patterns change. Using three different surveys collected by three different survey organizations with three different sets of subjects, and using two distinct measures of accessibility, we find the hypothesized relationships between accessibility, journey to work, and time at work to be fairly stable over time (although the magnitudes do vary). This means that adjusting land use patterns to increase the number of workers living in job-rich areas and the number of jobs in labor-rich areas is a likely to remain a reliable way of reducing auto commute durations.

\section{References}

Brosnan, M. P. (2014), Accessibility and the allocation of time - Changes in travel behavior 1990-2010, Master's thesis, University of Minnesota.

Cao, X. (2015), Telecommuting and its relationships with travel and residential choices - An exploration of the 2000 and 2010 regional travel surveys in the Twin Cities, in: Travel behavior over time, Technical Report 2015-23, Minnesota Department of Transportation. 
Cao, X., Mokhtarian, P. L. and S. L. Handy (2010), Neighborhood design and the accessibility of the elderly An empirical analysis in northern California, in: International Journal of Sustainable Transportation, Vol. 4, No. 6, 347-371.

Cervero, R. and K. L. Wu (1998), Sub-centring and commuting - Evidence from the San Francisco bay area, 1980-90, in: Urban studies, Vol. 35, No. 7, 1059-1076.

El-Geneidy, A. M. and D. M. Levinson (2006), Access to destinations - Development of accessibility measures, Technical report, Minnesota Department of Transportation.

Geurs, K. T. and B. van Wee (2004), Accessibility evaluation of land-use and transport strategies - Review and research directions, in: Journal of Transport geography, Vol. 12, No. 2, 127-140.

Gordon, P., Richardson, H. W. and M. J. Jun (1991), The commuting paradox evidence from the top twenty, in: Journal of the American Planning Association, Vol. 57, No. 4, 416-420.

Grengs, J. (2015), Nonwork accessibility as a social equity indicator, in: International Journal of Sustainable Transportation, Vol. 9, No. 1, 1-14.

Guidelines, M. G. M. (n.d.), Transportation analysis zones 2000, http://www.data_nder.org/metadata/taz2000 .html.

Hansen, W. (1959), How accessibility shapes land use, in: Journal of the American Institute of Planners, Vol. 25, No. 2, 73-76.

Haugen, K. (2011), The advantage of 'near' - Which accessibilities matter to whom?, in: European Journal of Transport and Infrastructure Research, Vol. 11, No. 4, 368-388.

Levinson, D. and K. Krizek (2015), The end of traffic and the future of transport, Amazon Digital Services, Inc.

Levinson, D. M. (1998), Accessibility and the journey to work, in: Journal of Transport Geography, Vol. 6, No. $1,11-21$.

Levinson, D. M. and S. Kanchi (2002), Road capacity and the allocation of time, in: Journal of Transportation and Statistics, Vol. 5, No. 1, 25-46.

Levinson, D. M. and A. Kumar (1994a), Multimodal trip distribution - Structure and application, in: Transportation Research Record 1466, 124-124.

Levinson, D. M. and A. Kumar (1994b), The rational locator - Why travel times have remained stable, in: Journal of the American Planning Association, Vol. 60, No. 3, 319-322.

Levinson, D. M. and A. Kumar (1995), Activity, travel and the allocation of time, in: Journal of the American Planning Association, Vol. 61, No. 4, 458-470.

Levinson, D. M. and A. Kumar (1997), Density and the journey to work, in: Growth and Change, Vol. 28, No. 2, 147-172.

Levinson, D. M. and Y. Wu (2005), The rational locator re-examined, in: Transportation, Vol. 32, No. 2, 187202.

Melo, P., Graham, D., Levinson, D. and S. Aarabi (2013), Agglomeration, accessibility, and productivity - Evidence for urbanized areas in the US, Paper submitted for the Transportation Research Board 92nd Annual Meeting.

Metz, D. (2010), Saturation of demand for daily travel, in: Transport Reviews, Vol. 30, No. 5, 659-674.

Millard-Ball, A. and L. Schipper (2011), Are we reaching peak travel? - Trends in passenger transport in eight industrialized countries, in: Transport Reviews, Vol. 31, No. 3, 357-378.

Mohring, H. (1972), Optimization and scale economies in urban bus transportation, in: The American Economic Review, Vol. 62, No. 4, 591-604.

Mokhtarian, P. L. and C. Chen (2004), TTB or not TTB, That is the question - A review and analysis of the empirical literature on travel time (and money) budgets, in: Transportation Research Part A: Policy and Practice, Vol. 38, No. 9, 643-675.

Owen, A. and D. M. Levinson (2012), Access to destinations - Annual accessibility measure for the Twin Cities metropolitan area, Technical report, Minnesota Department of Transportation.

Owen, A., Schoner, J. and D. M. Levinson (2015), Appendix a development of the travel behavior over time database, in: Travel behavior over time, Technical Report 2015-23, Minnesota Department of Transportation.

Pisarski, A. E. (1987), Commuting in America - A national report on commuting patterns and trends, executive summary.

Pisarski, A. E. (1996), Commuting in America II, The second national report on commuting patterns and trends. 
Pisarski, A. E. (2006), Commuting in America III, The third national report on commuting patterns and trends, No. 550, Transportation Research Board.

Schwanen, T. and M. Dijst (2002), Travel-time ratios for visits to the workplace - The relationship between commuting time and work duration, in: Transportation Research Part A: Policy and Practice, Vol. 36, No. 7, 573-592.

Shen, Q. (1998), Location characteristics of inner-city neighborhoods and employment accessibility of low-wage workers, in: Environment and planning B: Planning and Design, Vol. 25, No. 3, 345-365.

Tschopp, M., Fröhlich, P. and K. W. Axhausen (2005), Accessibility and spatial development in switzerland during the last 50 years - A multilevel regression approach, in: Levinson, D. and K. Krizek (Eds.), Access to destinations, Elsevier Oxford, 361-376.

United States Census Bureau (2012), Statistical Abstract of the United States, Technical report, United States Census Bureau.

United States Census Bureau (2013), Computer and internet use in the United States, Technical report, United States Census Bureau.

United States Department of Commerce (1944), Manual of procedures for home interview traffic studies, Technical report, United States Department of Commerce.

United States Department of Labor (2014), Labor force statistics from the current population survey, http://data.bls.gov/timeseries/LNS11300000.

United States Department of Transportation, Federal Highway Administration (2013), Annual vehicle miles traveled, Technical report, United States Department of Transportation, Federal Highway Administration.

VanWee, B. and K. Geurs (2011), Discussing equity and social exclusion in accessibility evaluations, in: European Journal of Transport and Infrastructure Research, Vol. 11, No. 4, 350-367.

Vickerman, R. W. (1974), Accessibility, attraction, and potential - A review of some concepts and their use in determining mobility, in: Environment and Planning, Vol. 6, No. 6, 675-691.

Wachs, M. and T. G. Kumagai (1973), Physical accessibility as a social indicator, in: Socio-Economic Planning Sciences, Vol. 7, No. 5, 437-456.

Weiner, E. (2012), Urban transportation planning in the United States - History, policy and practice, Springer Science \& Business Media.

Yang, J. and J. R. Ferreira (2005), Evaluating measures of job-housing proximity - Boston and Atlanta, 19802000, in Levinson, D. and K. Krizek (Eds.), Access to Destinations, Kidlington, Oxford, Elsevier Ltd., 171-192. 


\section{Nomenclature}

Table 6

Variables used in regressions

\begin{tabular}{|c|c|}
\hline \multicolumn{2}{|c|}{ Demographic and socio-economic variables } \\
\hline Age $10-19[0,1]$ & 1 if individual aged $10-19,0$ otherwise \\
\hline Age $20-29[0,1]$ & 1 if individual aged $20-29,0$ otherwise \\
\hline Age $30-39[0,1]$ & 1 if individual aged $30-39,0$ otherwise \\
\hline Age $40-49[0,1]$ & 1 if individual aged $40-49,0$ otherwise \\
\hline Age $50-59[0,1]$ & 1 if individual aged 50-59, 0 otherwise \\
\hline Age $60+[0,1]$ & 1 if individual aged $60+, 0$ otherwise \\
\hline Children & Nuber of children 0 - I6 in the household \\
\hline HH size & Number of persons in the household \\
\hline Male $[0,1]$ & 1 if individual is male, 0 otherwise \\
\hline SF home $[0,1]$ & 1 if individual lives in a single family home, 0 otherwise \\
\hline VPD & Number of vehicles licensed per driver \\
\hline \multicolumn{2}{|c|}{ Accessability variables } \\
\hline $\mathrm{A}_{\mathrm{iEa}}, \mathrm{A}_{\mathrm{iEt}}$ & Origin (home-end) accessibility to employment, by auto, transit \\
\hline $\mathrm{A}_{\mathrm{iRa}}, \mathrm{AiRt}$ & Origin (home-end) accessibility to population (housing for DC), by auto, transit \\
\hline $\mathrm{A}_{\mathrm{jEa}}, \mathrm{A}_{\mathrm{jEt}}$ & Destination (work-end) accessibility to employment, by auto, transit \\
\hline $\mathrm{A}_{\mathrm{jRa}}, \mathrm{A}_{\mathrm{jRt}}$ & Destination (work-end) accessibility to population (jousing for DC), by auto, transit \\
\hline $\mathrm{D}_{\text {io }}$ & Distance $(\mathrm{km})$ between origin (home-end) and IDS tower (miles, White House) \\
\hline $\mathrm{D}_{\mathrm{jo}}$ & Distance $(\mathrm{km})$ between destination (workplace) and IDS tower (miles, White House) \\
\hline $\mathrm{T}_{\mathrm{W}}$ & Time spent at work \\
\hline $\mathrm{T}_{\mathrm{E}}$ & Travel time to work \\
\hline WT & Number of work trips (a trip that had work or work-related as ist destination) \\
\hline
\end{tabular}

Source: own definitions. 